\title{
The Value in Procreation: A Pro-tanto Case for a Limited and Conditional Right to Procreate
}

\author{
Tim Meijers ${ }^{1}[0$
}

Published online: 5 February 2020

(C) The Author(s) 2020

\section{Introduction}

Having children is an important aspect of peoples' lives. I will take the intuition that there is something valuable about procreation as a starting point, and asks whether we can appeal to the value of procreation when engaged in liberal justification.

This is an important question philosophically speaking, but it also has important implications. There is a lively debate, both in philosophy and society at large, about constraints on the right to procreate as well as about government family policies. The strength and the nature of the interest people have in procreation has implications for both of these debates. We cannot take a position, for example, on the permissibility of procreation in the light of sustainability issues, without a view on the value in procreation. In this paper I offer such an account.

The aim of this paper is limited. First, this paper is about intentional voluntary procreation, not about cases where people are forced (by persons or circumstances) to procreate, or cases where people procreate unintentionally. Second, the view is incomplete. The view offered here does not offer conclusive arguments about whether procreation is all-things-considered (im)permissible. It offers one side of the story: an account of what makes procreation valuable, which will need to figure in any judgement about what is, all things considered, permissible. Nor does the paper address questions about the harm or benefit of coming into existence, which also has to figure in all things considered judgements. ${ }^{1}$

\footnotetext{
${ }^{1}$ This last caveat is particularly significant. Some argue that it is always wrong to bring people into existence, at least pro-tanto. See David DeGrazia, Creation Ethics. (Oxford: Oxford University Press, 2012); and Seana Shiffrin, "Wrongful life, procreative responsibility, and the significance of harm", Legal Theory, Vol. 5, No. 2. (1999): 117-148. Others argue it is wrong full stop, see David Benatar, Better Never to Have Been (Oxford: Oxford University Press 2004). In order for procreation to be all things considered permissible - in general or in a particular case - one would have to at least show that the latter positions is incorrect.
}

Tim Meijers

t.meijers@phil.leidenuniv.nl

1 Institute for Philosophy, Leiden University, Leiden, The Netherlands 
One clarification is in order. By procreator(s)', I mean the person(s) whose desire to create a new life leads to the procreative act, now or in the future. Usually these are the biological procreators. In cases of for example surrogacy, the future parents are the procreators - not the doctor or the surrogate. This definition allows for more or less than two procreators, and a biological link (gestational or biological) between procreators and the child is neither necessary nor sufficient. Genetic gestational procreation is one way to procreate.

This paper will proceed as follows. Section 2 will argue that we need an account of the value of procreation. Section 3 asks whether liberal neutrality allows for an appeal to such account when justifying policy or individual action. Section 4 argues procreation is not a basic liberty, though section 6 argues that it is instrumental to other basic liberties. Section 7 looks into the value of self-extension through procreation and argues that this either collapses into the importance of future generations more generally (discussed in section 5), or into the value of parenthood. Section 8 briefly looks into the possibility that there is something particularly valuable about genetic self-extension.

\section{Why the Value in Procreation?}

Do we need a view on the value of procreation? After all 'that procreation is very important seems too obvious to require further defence'. ${ }^{2}$ Perhaps a presumption in favor of reproductive liberty suffices? ${ }^{3}$

The presumption: given the importance of the right to procreate, people are free to act on their wish to procreate unless sufficiently weighty reasons against doing so can be offered.

The idea that the burden of proof lies with those who want to limit freedom is plausible. That procreation is considered worthy of protection is reflected in several international treaties, often in reference to the Universal Declaration's right to found a family: 'men and women of full age, without limitation due to race, nationality or religion, have the right to marry and found a family'. ${ }^{4}$ This right is usually thought of as a liberty right, barring intervention in reproductive decisions.

Yet, there are several reasons to believe that there are moral limits to the right to procreate. Arguably procreation wrongs a child if she will live a life not worth

\footnotetext{
${ }^{2}$ See DeGrazia, op. cit., p. 155

3 See John A. Robertson, J. A., Children of Choice (Princeton: Princeton University Press, 1996), p. 24

4 See United Nations Universal Declaration of Human Rights. (New York: United Nations, 1948). UN Secretary-General Thant linked this right to procreation in 1967: "The Universal Declaration of Human Rights describes the family as the natural and fundamental unit of society. It follows that any choice and decision with regard to the size of the family must irrevocably rest with the family itself, and cannot be made by anyone else". See https://www.un.org/en/development/desa/population/theme/rights/index.asp (accessed 14-10-2019).
} 
living, or if she will be severely disadvantaged. ${ }^{5}$ Perhaps procreation is impermissible if it imposes excessive net costs on third parties, such as society or future generations because of sustainability issues: perhaps intergenerational justice or environmental justice requires that certain demographic goals are met. ${ }^{6}$

Debates about the fair distribution of the burdens and benefits of parenthood might imply limits on the right to procreate. Defenders of the so-called anti-sharing view argue that parents have to internalize the negative externalities that come with their decision to parent: requiring others to contribute would be unfair. ${ }^{7}$ A link to procreation is easily made. Suppose that, assuming a just background distribution, a couple cannot afford all the costs (internal and external) that come with procreation. If they procreate, they will either impose costs on others or the child's needs will not be met. Assuming the latter is impermissible, others will have to 'pick up the slack'. These procreators, on the anti-sharing view, unjustly impose costs on others. Casal and Williams suggest this:

[...] we might say to legislators in a society where some parents are unjustly indifferent to the effects on others of their procreative decisions, that justice to their children demands that they not be taxed more highly. To do so, however, need not exempt those parents from criticism at the bar of egalitarian justice. ${ }^{8}$

However, whether we may criticize such procreators at the bar of justice depends on our view on the value of procreation. Whether these considerations in favor of moral limits on procreation are decisive depends both on the costs imposed as well as on what is at stake for the prospective procreators. Without a view on the value of procreation, these are mere considerations in favor of criticism at the bar of justice.

The claim that prospective procreators lack the right to procreate in the light of parental justice or environmental considerations implicitly assumes that procreation is not a special kind of activity which merits special protection: distributive considerations that apply to other plans in life - say, mountaineering or catamaran sailing - apply to procreation. This is the no special status claim. This is a possible answer to the question raised by this paper.

\footnotetext{
5 See Onora O'Neill, "Begetting, Bearing and Rearing," in O. O'Neill and W. Ruddick, eds., Having Children (Oxford: Oxford University Press, 1977), p. 29; Bonnie Steinbock "Wrongful life and Procreative Decisions," in David Wasserman and Melina Roberts, ed., Harming Future Persons (Dordrecht: Springer, 2009), p. 155.

6 See Carol A. Kates, "Reproductive liberty and overpopulation," Environmental Values, Vol. 13, No. 1 (2014): 51-79; Sarah Conly, One Child (Oxford: Oxford University Press, 2016); Thomas Young "Overconsumption and Procreation: Are they Morally Equivalent?" Journal of Applied Philosophy, Vol. 18, No. 2 (2001):183-192. Tim Meijers, "Citizens in Appropriate Numbers," Canadian Journal of Philosophy, Vol. 40, No. 2-3 (2017): 246-268.

7 See Paula Casal and Andrew Williams "Rights, Equality and Procreation", Analyse und Kritik Vol 17(1995): 93-116; Eric Rakowski, Equal Justice (Oxford: Oxford University Press, 1991). For recent defenses of the pro-sharing view, see Serena Olsaretti "Children as Public Goods?" Philosophy \& Public Affairs, Vol. 31, No. 3 (2013): 226-258; Sandrine Blanc and Tim Meijers "Firms and Parental Justice," Economics \& Philosophy (forth): Advanced Access.

${ }^{8}$ Casal and Williams, op. cit., pp. 163-164.
} 
In the case of conflict between the morally relevant interests of procreators and those of others, we cannot appeal to the presumption because it cannot tell us whether any of the considerations against the moral permissibility of procreation actually render procreation impermissible. The presumption affirms the importance of procreation, without giving reasons for its importance, so we cannot determine what kind of reasons are strong enough to override it. In order to decide whether procreation is morally permissible in the light of parental justice considerations, environmental considerations and the like, we need an account of the value in procreation.

There are two reasons why we need to think about the value in procreation in a liberal theory. First, people tend to think that procreation is special. Can liberal assign a special place to procreation as a matter of justice, or this simply a matter of the good? Second, we cannot evaluate policies that are aimed at or impact peoples' capabilities to have children, nor can we judge an individual's behavior as permissible or impermissible without it. ${ }^{9}$

\section{Procreation and the Good Life}

One could argue that the central question of this paper is based on a misconception, and that liberal neutrality precludes assigning a special place to procreation:

neutrality objection: questions about the value of a particular activity or plan are part of a view of contestable conceptions of the good life, not of the right. Hence, the value in these activities cannot be appealed to when engaged in liberal justification.

This objection could be offered by those who defend the no special status claim. In response, one might either reject liberal neutrality and accept a form of (liberal) perfectionism, or try to show that some of the value in procreation can be appealed to by liberals without impermissible appeals to controversial conceptions of the good life. I argue we should take the latter route, and tries to show that liberal theories can appeal to the value in procreation when engaged in liberal justification.

Most liberal theories of justice, without taking a position on what a good life consists in, do rely on a thin theory of the good. ${ }^{10}$ Some liberal theorists focus on the distribution of means and capacities to pursue plans in life. These theorists aim to

\footnotetext{
9 Robert Taylor identifies a similar tension between neutrality and support for parenthood. He resolves it by a (plausible) appeal to the importance of raising children to be persons. Ingrid Robeyns aims to show too, that procreation is not morally equivalent to other activities. See Robert S. Taylor, "Children as Projects and Persons," Social Theory and Practice, Vol. 35. No. 4 (2009): 246-271; Robeyns, I. "Is Procreation Special?" draft manuscript on file with author.

${ }^{10}$ This is not true for full neutralism, see for a discussion Simon Caney "Impartiality and Liberal Neutrality," Utilitas, Vol. 8, No. 03 (1996): 273-293; for a defense Jonathan Quong, Liberalism without Perfection (Oxford: Oxford University Press, 2010).
} 
identify certain all-purpose means for pursuing a broad range of plans on the basis of this thin theory of the good. The distribution of these goods is a matter of justice, whereas the distribution of other things is not. For example, for Rawlsians, the distribution of income and wealth is a matter of justice, whereas the distribution of stamp-collections (no matter how much one may value them) is not. There is little agreement about the distribution of what exactly - opportunities, resources, welfare, primary goods, capabilities, etc. - justice is concerned with, i.e. the metric question. However, in spite of this disagreement, there is much more consensus about which particular goods (the distribuenda) are relevant from the point of view of justice. ${ }^{11}$ Health is a good example: whatever one's position on the metric debate, be it capabilities or resources, one will agree that the distribution of health matters for justice. ${ }^{12}$ The arguments offered here aim to have a similarly broad appeal, especially to those theories of justice which focus on the distribution of opportunities to realize plans in life (resources, capabilities, primary goods), but some arguments will appeal to those who defend outcome-focused metrics (such as welfare) as well.

A defining feature of liberal theories is their commitment to people's ability to form their conception of the good life ${ }^{13}$, to pursue plans that they themselves endorse (within the limits of the morally permissible). ${ }^{14}$ The protection of the capacity to make plans - whether one calls this capacity self-determination, autonomy, personhood - takes priority over other justice considerations. A theory of justice also needs a view on the fair distribution of the relevant means. Activities granting access justice-relevant goods, play a different role in theories of distributive justice than those activities that do not. Take work for example, or positions of political power. Both give access to important goods, like income and wealth, power and self-respect. ${ }^{15}$ Hence, we treat access to these positions with special care. Access to positions of advantage is regulated by principles of justice, and if we can show that the position of procreator is such a position, we have reasons of justice to be concerned with access to and distribution of access to this position. This can be done without an impermissible appeal to comprehensive views about the importance of engaging in particular kinds of activities.

Consider an analogy with the arts. Dworkin makes a liberal argument that although the arts are sometimes considered a part of peoples' conceptions of the good, they arguably fall under the purview of justice. He distinguishes two strategies to defend cultural subsidies. ${ }^{16}$ The Lofty approach appeals to the role that the arts

\footnotetext{
11 See Anca Gheaus, "Hikers in flip-flops Luck Egalitarianism Democratic Equality and the Distribuenda of justice," Journal of Applied Philosophy, Vol. 35, No. 1 (2018): 54-69.

12 See Elizabeth Anderson, "Justifying the Capabilities Approach to Justice," in Harry Brighouse and Ingrid Robeyns, eds., Measuring Justice (Cambridge: Cambridge University Press, 2010): 81-100.

13 See Will Kymlicka, Liberalism, Community and Culture (Oxford: Clarendon Press, 1991), p. 12.

14 On this view autonomy is a status that needs to be protected, while perfectionists like Raz and Griffin use the term differently, i.e. as an ideal people should aspire to. See Joseph Raz, Morality as Freedom (Oxford: Oxford University Press, 1984); James Griffin, Well-being: Its Meaning, Measurement, and Moral Importance (Oxford: Oxford University Press, 1986).

15 See Anca Gheaus and Lisa Herzog, “The Goods of Work (Other Than Money!)," Journal of Social Philosophy, Vol. 47, No. 1 (2016): 70-89.

16 See Ronald Dworkin, A Matter of Principle (Oxford: Oxford University Press, 1985), p. 221.
} 
play in leading the good life. A perfectionist could claim that procreation and parenthood are essential elements of the good life. ${ }^{17}$ Moderate perfectionists could argue that procreation and parenthood are excellent opportunities to attain some - virtues of excellence - that are part of the good life. These approaches are incompatible with non-perfectionist liberal views.

The economic justification takes a different route. Funding the arts may be permissible because it corrects market failures. Perhaps everybody will be less well off (financially) without subsidies. It may be too expensive for individuals to (say) pay an admission price that would cover costs, even though the museum would be beneficial economically, for example because it will attract visitors who will then spend money on coffee and souvenir shops as well, creating jobs. Similar arguments apply to procreation. Subsidizing procreation may be justifiable if fertility levels are economically suboptimal: say, as an incentive to make sure procreation happens at a desirable rate. ${ }^{18}$

Although the economic justification is compatible with key liberal commitments, Dworkin argues that it fails to do justice to what makes culture valuable. The economic justification offers a poor account of the value in procreation, too. Dworkin thinks there are other valuable goods that the arts provide, such as a shared cultural language, sources of value, standards of beauty, a connection with past generations, and so on. This does not establish that the state ought to fund the arts, or by how much. But it does show that, because of its value it qualifies for state support, in cases of 'undersupply', for example, or if access to art is restricted to a lucky few. ${ }^{19}$ The present paper aims at doing just that for procreation, by showing that there is a strong pro-tanto case for supporting procreation. I defend the view that procreation gives access both to goods 1) crucial for realizing any conception of the good and 2) necessary for the realization of a broad range of conceptions of the good. To be sure, one does not need to procreate oneself in order to gain access to the goods of procreation.

Dworkin's attempt is one example of an argument which tries to show that liberal theories can appeal to the value of certain practices while remaining faithful to liberal justification. Numerous other examples could be mentioned, such as Kymlicka's defense of the value of culture; Brighouse and Swift's defense of the value of the family; Gosseries's discussion of the value of bio-diversity. ${ }^{20}$ Whether one finds these particular arguments convincing, a commitment to liberal neutrality does not exclude an appeal to the value in certain activities for justifying rights. It requires us to think about what the value and goods are at stake in certain practices. As long as they are valuable for reasons internal to a liberal view, liberals qua liberals can grant special status to certain activities.

\footnotetext{
17 See Rosalind Hursthouse, Beginning Lives (Oxford: Blackwell, 1987).

18 See Casal and Williams op. cit., p. 104.

19 See Dworkin, A Matter of Principle, op. cit., p. 233.

20 See Will Kymlicka, Multiculturalism (Oxford: Oxford University Press, 1995); Harry Brighouse, and Adam Swift, Family Values (Princeton: Princeton University Press, 2014); Axel Gosseries, Penser la justice entre les générations (Paris: Aubier, 2004), pp. 251-258.
} 


\section{Procreation as a Basic Liberty}

Does the right to procreate belong on the list of basic rights and liberties, to which liberal theories of justice give priority? Fabre suggests this:

according to Rawls, one cannot sacrifice fundamental rights and liberties for the sake of great material advantage. In so far as the right to reproduce is a fundamental right, it follows that it cannot be curtailed for the sake of bringing about great material advantages for our successors. ${ }^{21}$

Something is a basic liberty if and only if the liberty is needed to protect peoples' agential capacities, that is the higher order capacity to form our own plans in life, pursuing them while remaining within the limits of what is morally permitted (whether it is labelled moral powers, personhood, agency or self-determination). ${ }^{22}$

Freedom of conscience and free speech are clearly needed for the capacity to (re-) form plans, to learn about other views, etc. ${ }^{23}$ The connection between procreation and autonomy is not so straightforward. Not being able to procreate prevents one from pursuing only conceptions of the good which involve procreation. Similarly, not owning a Ferrari blocks all plans in life that involve Ferrari-ownership. But we are not entitled to everything we need to realize any conception of the good life.

Even if procreation is not itself protected by a basic right, perhaps it can be indirectly linked to other basic rights such as bodily integrity. Or one may point out that restricting procreative freedom is a threat to equal basic rights and liberties, because it affects women more than men. Both concerns rely on the claim that because enforcing limits on procreation is impermissible, people have a (liberty-) right to procreate.

This argument shows that the enforcement of limits on procreation is impermissible, not that procreation is morally permissible. To return to Fabre's suggestion: limiting procreation in order to benefit future generations in ways that violate basic rights and liberties is impermissible not because intervention violates a right to procreate, but because it involves impermissible violations of other basic rights. ${ }^{24}$ On this argument a liberty-right to procreate is at most a correlate of basic liberties. Although this is not an insignificant conclusion, procreation plays a more profound role in peoples' lives as well.

\footnotetext{
${ }^{21}$ Cécile Fabre, Justice in a Changing World (London: Polity Press, 2007), p. 34.

${ }^{22}$ See John Rawls, Political Liberalism (New York: Columbia University Press, 2005), pp. 310-324; Robert S. Taylor, "Rawls' Defence of the Priority of the Liberties: A Kantian Reconstruction," Philosophy and Public Affairs, Vol. 31, No. 3 (2003): 246-271.

${ }^{23}$ See Rawls, Political Liberalism, op. cit., lecture VIII; Dworkin, R., Justice for Hedgehogs (Cambridge, MA: Harvard University Press, 2011), pp. 368-371.

${ }^{24}$ See O’Neill, op. cit., p. 38.
} 


\section{Continuation and Future Generations}

Following Scheffler, imagine that, as in P.D. James's dystopic novel Children of Men, everybody becomes infertile. ${ }^{25}$ Humanity will become extinct within a generation. Most would regret this, but is it a bad outcome from the point of view of a liberal theory of justice? Perhaps it is a loss from a cosmic point of view: humanity, and perhaps all intelligent life, would disappear. Some utilitarians would regret the end of human life, if it were to be sub-optimal in terms of overall utility. Let's assume extinction is bad if and only if it is bad for those people who suffer from it by being part of the last generation, not for those who never come into existence because of it. ${ }^{26}$ Would extinction be bad for existing people? This is a fascinating question, because it turns the question of intergenerational justice upside down: how do future generations affects existing people? I distinguish between two ways in which future generations, and procreation as the way to create them, have value on the collective level: the dependency argument and the meaning based argument. ${ }^{27}$

Dependency arguments. Societies depend on the influx of new people for their functioning over time. Without the arrival of new people, the economy would not keep going. Who will fund pensions and healthcare? Who will staff factories, hospitals, or government? Society needs 'citizens in appropriate numbers' in order for society to continue over time. ${ }^{28}$

In addition, individual wellbeing also depends on the renewal of generations. Gheaus summarizes this nicely:

A new generation is needed in order to avoid that people die from necessarily painful and probably premature deaths. Without new generations, the economy would collapse. It is unavoidable that many people end their lives in a state of dependency (the old, the ill, the disabled) and if there was no one to care for them they would die hungry, thirst, without pain relief and other palliative care. $^{29}$

Basic needs will go unmet without newborns, and society will eventually collapse. Without procreation the institutions necessary for the protection of the basic liberties would not be sustained over time. Hence, part of the value of procreation lies in the fact that without it, basic needs and basic rights would go unmet and just institutions could not be sustained. Hence, we could formulate two dependency arguments.

\footnotetext{
25 See Samuel Scheffler, Death and the Afterlife (Oxford: Oxford University Press, 2013), pp. 38-39.

26 See Elizabeth Finneron-Burns, "What's Wrong with Human Extinction," Canadian Journal of Philosophy Vol. 47, No. 2-3 (2017): 327-343.

27 See Tim Meijers, "Climate Change and the Right to One Child" in Gerhard Bos and Marcus Düwell eds., Human Rights and Sustainability (London: Routledge, 2016): 281-294.

28 See Rawls, Political Liberalism, op. cit., p. 467; Meijers "Citizens in Appropriate Numbers" op. cit.

29 Anca Gheaus "Could There Ever be a Duty to have Children," in Sarah Hannan, Samantha Brennan and Richard Vernon, eds., Permissible Progeny (Oxford: Oxford University Press, 2015), p. 94.
} 
Care-based argument: people have a fundamental interest in some people having on aggregate sufficient children to ensure adequate care and the protection of basic rights and liberties (and their effective use).

Stable just institutions argument: people have a fundamental interest some people having on aggregate sufficient children to ensure that just institutions continue to function and exist.

On the collective level, procreation is needed to protect basic needs, and basic needs must be met before people can make effective use of their basic liberties. ${ }^{30}$ This connects procreation indirectly to the protection of basic needs. Just institutions protect, among others things, basic rights and liberties, and hence procreation is directly linked to these as well. On a national level replacement migration might do some of the work needed to meet the care-based and sustainability of just institutions related worries, but for the world as a whole there is no alternative to procreation. ${ }^{31}$

The loss of meaning argument. The value of future generations goes beyond this type of dependency. Take the Children of Men example again. Once we find out that we live in a childless world, would our plans of life be unaffected by the fact that humanity ends with us? The main character in James's novel thinks the following to himself:

I can understand how the aristocrats and great landowners with no hope of posterity leave their estates untended. ... [O]ur minds reach back through the centuries for the assurance of our ancestry and, without the hope of posterity, for our race if not for ourselves, without the assurance that we being dead yet live, all pleasures of the mind and senses sometimes seem to me no more than pathetic and crumbling defences up against our ruin. ${ }^{32}$

Many of our plans in life transcend the span of our own lives. We may be interested in human progress, in the future of our country, village, street or clubs. We may want to preserve historical buildings, keep traditions or languages alive, continue literary, philosophical or artistic traditions, protect things of beauty, and so on. One could value these projects intrinsically, while perhaps some want to be remembered for their contributions to these projects. Here is a hypothesis about the importance of future generations: future generations matter because they are instrumentally necessary for our plans in life to succeed.

Formulated this way, it may appear as though future generations are merely instrumental for pursuing plans in life. This claim is both too strong and too weak. Too strong, because people can still have meaningful plans in the face of human extinction: one could find great purpose in closing shop in a decent manner. Think of Justine in Lars von Trier's Melancholia. She suffers from severe depression, but regains a sense of purpose (taking care of her nephew) in the face of the end of

\footnotetext{
${ }^{30}$ See Meijers, "Citizens in Appropriate Numbers". For a discussion of the fair value of the liberties, see Paula Casal, "Why Sufficiency is Not Enough," Ethics, Vol. 117, No. 2 (2007): 324-325.

${ }^{31}$ See Paul Bou-Habib, "The Case for Replacement Migration", Journal of Political Philosophy, Vo. 27, No. 1 (2019): pp. 67-86.

${ }^{32}$ P.D. James, Children of Men (London: Faber and Faber, 1992).
} 
our planet. Perhaps people will find a purpose in preserving some of mankind's' achievements, or offer comfort, support and guidance to a dying species. Although we would certainly have to reconsider our plans in the light of approaching extinction, the end of humanity does not undermine all possible meaningful projects. It merely limits the range of options.

But the claim that it merely limits our options is too weak: this underestimates the importance of future generations for our plans in life. It is not just that we no longer have the means to pursue life-transcending plans, but the plans themselves will lose their meaning. The very point of the activity, tradition, or practice ceases to exist. As Scheffler points out, the presence of people after our deaths is more important to us than our own survival: the prospect of our own death does not touch our belief that things are worth doing, but the prospect of mankind disappearing would. A life could, then, still be meaningful but we can reasonably doubt whether it could still be a flourishing life: most people's current plans would lose their point and they would have to go through the painful process of formulating a new plan from an impoverished set of possibilities. ${ }^{33}$

Why do future generations infuse meaning into people's plans? Our life transcending projects make sense because they will be valued by people who exist after we are gone. Why contribute to big projects such as truth in science and philosophy, finding cures for diseases, preserving things and practices of beauty, without anyone who will benefit from these projects or continue the pursuit? Heyd claims that:

The projective aspect of human behaviour is vital to life's meaning both on the individual and collective levels. With no sense of growth, hope, progress or accomplishment, life would be senseless and self-perception and personhood absurdly narrow and impoverished. Après nous le deluge is, therefore, not an immoral principle, but rather a self-defeating attitude, which leaves little point and purpose to our lives. ${ }^{34}$

Compare this to what Rawls says about the social basis for self-respect:

When we feel that our plans are of little value, we cannot pursue them with pleasure or take delight in their execution. Nor plagued by failure and selfdoubt can we continue in our endeavors. It is clear then why self-respect is a primary good. Without it nothing may seem worth doing, or if some things

\footnotetext{
33 For similar claims, see Lukas Meyer, "More Than They Have A Right To" in Nick Fotion and Jan C. Heller, eds., Contingent Future Persons (Dordrecht: Springer, 1997): pp. 135-156; and Samuel Scheffler, Why Worry About Future Generations (Oxford: Oxford University Press, 2018); Janna Thompson, Intergenerational Justice (London: Routledge, 2009). Note, however, that only life-transcending projects requiring continued human existence are impossible. For those who think flourishing flora or fauna matter for their own sakes, there might still be life-transcending projects. I do not consider sci-fi scenarios where aliens who value similar things like humans show up: they could play, to some extent, the role that future generations play in providing meaning to our lives (if sufficiently like us).

34 David Heyd, Genethics (Berkeley, University of California Press 1994), p. 222.
} 
have value for us, we lack the will to strive for them. All desire and activity become empty and vain and we sink into apathy and cynicism. ${ }^{35}$

If Heyd is right, future generations play a similarly important role as the social basis for self-respect does. Formulating meaningful plans in life and being motivated to act on them would be hard without future generations, and - less controversially - the transitional cost of reformulating one's plan in life in view of human extinction, even though not impossible, is tremendous. ${ }^{36}$ Perhaps more importantly, extinction would impoverish the range of plans people could pursue: many of the things people find pleasing, challenging, valuable, and that infuse their lives with meaning would no longer make sense. Future generations are valuable, and part of the value of procreation is that it provides it:

Loss of meaning argument: People have a fundamental interest in some people having on aggregate sufficient children to make life-transcending projects possible.

Towards an individual right? Without further argument: these arguments tell us something about the aggregate level of procreation that is needed for the provision of these goods, not how procreative entitlements should be distributed. There are different ways to meet the aggregative demand. Consider two alternative policies. Policy A grants procreative entitlements to only a few families (say, 10 non-transferrable entitlements). Policy $B$ would distribute entitlements equally. Both distribute procreative entitlements give people an equal shot at becoming parents, say by allocating sets of entitlements by lottery. All competent and willing procreator-parents have an equal chance at realizing their conception of the good.

We should be in favor of policy $B$. One reason for an egalitarian distribution of procreative entitlements (+ parenthood) may be cultural diversity: different people are part of different life-transcending projects. And even if 'comprehensive enrollment ${ }^{37}$ in cultural projects is impermissible, inevitably children growing up in a certain environment will form their plans in life in reference and opposition to their surroundings. Distribution of procreative entitlements are one way to protect the diversity of life-transcending projects. Second, one may expect that procreative entitlements will need to be spread widely to protect access to self-extension and parenthood, to which we now turn.

\footnotetext{
35 John Rawls, A Theory of Justice (Cambridge, MA: Belknap Press of Harvard University, 1971), p. 440.

36 As Kymlicka, changing cultures is costly. Seeing one's culture (or other plans close to one's identity) disappear is equally, if not more, costly and painful. Kymlicka, Multiculturalism, ch. 5.

37 Comprehensive enrollment is the practice of raising children in such a way and with the aim that they will share their parents' comprehensive view of the good life. See Brighouse and Swift, Family Values, pp. 164-174.
} 


\section{Self-Extension}

Self-extension requires that other people take on certain of our features: our values, genetic material, plans, and the like. The previous section discussed the importance of future generations at the collective level, appealing to what one might call the importance of collective self-extension. However, we can also argue that it is important that we have the possibility of overcoming mortality at a more individual level. Our lives are finite: sooner or later we all die. Having children is a way to create and contribute to the world after we are gone. One may think that procreation is valuable because it allows people to extend themselves into the future. According to Heyd,

[b]egetting children is a sort of self-expansion, an attempt to extend one's existence, a guarantee for a kind of continuity of the self beyond its individualbiological bounds. ${ }^{38}$

Is procreation valuable because it allows us to overcome mortality through selfextension? Taken literally, this view is both mistaken and objectionable. No matter how much a child looks like her procreator, she is a distinct person. Treating her as an extension of the procreator in a literal sense violates the distinction between persons: the child is her own person. This does not mean that people may not believe that their child is an extension of themselves in a relevant way, or that it is impermissible to procreate informed by this belief. People are free to believe all sorts of things, even if they are nonsensical, and act on them if they do so within the limits of the morally permissible. Having a child for reasons of self-extension may be permissible, but raising that child as if she were an extension of her creator would be impermissible ${ }^{39}$ : the child should be able to form and act on her own plans in life, and not be raised to realize the plan her procreator-parent has in mind ${ }^{40}$ It would, for example, be impermissible for a procreator-parent to realize her unattained dream of becoming a pharmacist by forcing her child to go down that particular career path.

A more plausible claim is that the value of procreation lies in vicarious immortality, in living by proxy. Although it is

no more than an illusory, deceptive consolation for those who strive to break the limits of mortality, it is the only kind of immortality we can try to achieve. $^{41}$

This avoids the pitfall of violating the distinction between persons. In order to show that this is a good way to ground the value of procreation, we need to ask two

\footnotetext{
${ }^{38}$ Heyd, Genethics, p. 215.

39 Although one may argue that being a good enough parent requires having a set of beliefs which includes the belief that your child is a person in her own right. I thank an anonymous reviewer for pointing this out.

40 See Brighouse and Swift, Family Values; Matthew Clayton, Justice and Legitimacy in Upbringing (Oxford: Oxford University Press, 2006).

41 See Heyd, Genethics, op.cit., p. 215.
} 
questions: is the capacity to be vicariously immortal valuable, and is procreation necessary to realize this?

For reasons given in the section about future generations, we can answer the first question in the affirmative. Self-extension is an important good: if we had to confine our plans to the span of our own life, this would greatly impoverish our opportunities to pursue plans that are meaningful. One of the reasons for this may be our fear of dying. Knowing that we do not disappear completely after we die, that we leave something behind, allows for some reconciliation with the prospect of death. As Scheffler points out, the prospect of our own deaths is much less disturbing to us than the end of mankind, even if that occurs after we are gone (Scheffler 2013, 76). Having children is a particularly visible and tangible way to leave something behind.

Is procreation necessary for self-extension? As we have seen in the previous section, the answer on the individual level is "No". One can have life transcending projects without having children of one's own. This is (vicarious) non-genetic self-extension. One may object by way of an appeal to the particular importance of genetic self-extension. However, why would genetic self-extension be a particularly valuable way of projecting oneself into the future? It is only one possible way to extend oneself. More importantly, it appears to be a bad way to realize self-extension when taken in isolation. Did Rousseau and Thérèse extend themselves into the future in any relevant way when they procreated carelessly and had five children, abandoning them all as foundlings? Procreation, that is, is not sufficient for meaningful self-extension. Adoptive parents, taking good care of children not biologically their own, seem to be engaged in a more meaningful mode of self-extension than rash procreators. To summarize, having biological offspring is neither necessary nor sufficient for selfextension. Without an account of the way genetic self-extension would in itself be valuable, ${ }^{42}$ the apparent value of procreation for self-extension - vicarious immortality - seems to collapse either into the relevance of life-transcending projects more generally (and at which Rousseau seems to have been much better), discussed above, or into the importance of parenting. To these I now turn, before considering whether biological parenthood - genetic or gestational - is particularly valuable.

\section{The Parental Argument for Procreation}

One might claim procreation is special because it allows for the creation of a family and parent-child relationships. The right to a found a family in the Universal Declaration is often interpreted as a right to procreate. Yet parenting and procreating

\footnotetext{
42 Elizabeth Brake argues that procreation matters because it allows people to act on the belief 'that reproducing their [procreator; friends; family; loved one's] genes will benefit the world' (p. 143). Brake thinks this is the strongest pro-tanto reason for the permissibility of procreation in the face of non-trivial costs. Without further defense, this appeals to comprehensive ideals about what kind of world would be better. There might be ways to present this argument as liberally neutral (perhaps permission to extend one's genetic material into the future is a demand of social or relational egalitarianism -what treating each other as equals demands) - but I cannot pursue this thought here. Elizabeth Brake, "Creation Theory: Do Genetic Ties Matter" in Sarah Hannan, Samantha Brennan and Richard Vernon, eds., Permissible Progeny (Oxford: Oxford University Press, 2015): pp. 129-149.
} 
are distinct activities: one can do one without the other, for example when one either adopts or gives a child up for adoption. In this section I introduce two arguments for the importance of parenthood, and then show how they could be linked to procreation.

Imagine a society, Antifamila, where an otherwise benevolent dictator, Rex, implements Plato's vision for rearing children. ${ }^{43}$ After birth, children, without force, are placed in state-run orphanages. This way of raising children may be wrong for several reasons. Perhaps it is not good for children or for society's future. ${ }^{44}$ Perhaps it violates right of gestational parents and their involved partners to parent their child. ${ }^{45}$ More importantly, people would no longer be able to engage in parental relationships whatsoever. Imagine another ruler, Rex*, who bans red socks. Although both bans seem arbitrary and unjustified, the ban on the family seems much worse, and not only for the children born under Rex. The next sections aim to give two accounts for why this is correct.

Parental relationships. Imagine that children were produced in baby-factories. How should these children be distributed to parents? Should we give children to the best available parents, or should we evenly distribute children to those who are both willing and sufficiently competent to parent? Harry Brighouse and Adam Swift's dual interest account of parental rights provides reasons to think that sufficiently good parents should be eligible, too. They think the interest people have in engaging in parental relationships grounds a (limited and conditional) right to parent. Parenthood is important because:

The role enables them [parents] to exercise and develop capacities the development and exercise of which are, for many (though not, certainly, for all) crucial to them living fully flourishing lives. Through exercising these capacities in the specific context of intimately loving parent-child relationships, a parent comes to learn more about herself, she comes to develop as a person, and she derives satisfactions that otherwise would be unavailable. The successful exercise of this role contributes to, and its unsuccessful exercise detracts from, the success of her own life as whole. ${ }^{46}$

Parenting, they argue, is a way to access familial relation goods which can only be accessed through parenting. The relationship is non-substitutable by other (fiduciary) personal relationships because it combines four features: children are not in the relationship voluntarily; it is a paternalistic relationship; it inevitably includes shaping the child's values; and, finally, the spontaneous and unconditional love parents receive from their child.

\footnotetext{
43 See Plato, The Republic (Cambridge: Cambridge University Press, 2000), Book 5.

44 See Véronique Munoz-Dardé, "Is the family to be abolished then?" Proceedings of the Aristotelian Society, Vol 99 (1999): 37-56.

45 See Anca Gheaus, “The Right to Parent One's Biological Baby,” Journal of Political Philosophy, Vol. 20, No. 4, (2011): 432-455.

46 Harry Brighouse and Adam Swift, "Parents' Rights and the Value of the Family," Ethics Vol 117, No. 1 (2006), p. 95.
} 
The right Brighouse and Swift defend is both conditional and limited. It is conditional being a good enough parent. ${ }^{47}$ This is so both because the goods of parenthood can only be realized if one is a good enough parent, ${ }^{48}$ as well as because of the weighty interest of the child in having good enough parents. It is limited, because only those powers and prerogatives necessary for the realization of the goods can be justified. This limits the kind of claims that can be made by an appeal to parental rights.

Brighouse and Swift say that their account seems 'moderately perfectionist', suggesting that their view may not be compatible with liberal neutrality. ${ }^{49}$ But at least some of the goods of parenthood they identify fit with a plausible understanding of a thin theory of the good - such as self-realization, intimate and loving relationships, self-knowledge, and challenging, meaningful activities. We could add important relational goods, ${ }^{50}$ such as love, trust, responsibility and a sense of belonging. Although the importance of relational goods cannot be elaborated here, any plausible currency of justice would have to place them among its distribuenda. ${ }^{51}$ One could give up the claims that parenting is uniquely valuable and that the ability to engage in this kind of relationship is fundamental, while at the same time claim that parenthood gives access to a whole range of goods. One only needs to point to the tremendous impact on the distributions of goods that each plausible theory of justice needs to consider relevant to show that the distribution of parental rights matters from the point of view of justice.

To see how the perfectionist charge can be met, compare parenthood to jobs. Like parenthood, jobs give access to a wide range of primary goods: self-respect, income, responsibility, and the like. Meaningful work is an important way to access primary goods. The fact that jobs and positions come with privileges and advantages is a reason to treat their distribution especially carefully, for example by placing access to jobs under fair equality of opportunity principles. If parenthood is an important way to access goods falling under a plausible thin theory of the good, this has important implications for the protection of access to this kind of relationship.

Granting people access to parenthood might be a way to make meaningful activities available to the masses. Rawls's description - albeit in a somewhat perfectionist vein - of the 'Aristotelian principle' rings true for parenthood:

Presumably complex activities are more enjoyable because they satisfy the desire for variety and novelty of experience, and leave room for feats of inge-

\footnotetext{
47 See also Liam Shields, "How Bad Can a Good Enough Parent Be?" Canadian Journal of Philosophy, Vol. 46, No. 2 (2016): 163-182.

48 Procreation is not sufficient to get access to the goods of parenthood: it requires both good enough parents, and possibly - but this requires further research - a certain level of health in the child.

49 See Brighouse and Swift, Family Values, p. 88.

50 'Relational resources are rather goods that are distinctively produced through and available within relationships or that are themselves constitutive of certain relationships.' Chiara Cordelli, "Justice as Fairness and Relational Resources," Journal of Political Philosophy, Vol. 23, No. 1 (2015), p. 90.

51 See Anca Gheaus, "How Much of What Matters Can We Distribute? Love, Justice and Luck," Hypathia, Vol. 24, No. 4 (2009): 63-83; Martha Nussbaum, Frontiers of Justice (Cambridge, MA: Belknap Press of Harvard University, 2006); Cordelli, op. cit.
} 
nuity and invention. They also evoke the pleasures of anticipation and surprise, and often the overall form of activity, its structural development, is fascinating and beautiful. ${ }^{52}$

Arneson also makes the connection between parenthood and meaningful work when he says: 'for people whose labor market prospects are poor, the opportunity to raise children is a very significant, perhaps the only feasible opportunity they have to engage in creative and meaningful work ${ }^{53}$ Parenthood, then, can be seen both as an important source of meaningful activities and a source of important primary goods. This gives some pro-tanto support for allocating the right to parent widely among willing and sufficiently capable parents because this is a good way to distribute access to these important goods.

There are several possible objections to Brighouse and Swift's account, an important one being that parenthood is not uniquely valuable: there are other ways to give people access to the goods at stake in parenthood. Parenthood, that is, is substitutable: there are other ways to access these goods. Even if this objection is right, it is limited. The goods at stake in parenthood are important, and access to parenthood is a way to distribute access to these important goods. If the goods at stake are important enough, there is at least a pro-tanto case compatible with liberal requirements for promoting access to opportunities to access these goods (parenthood being one among many).

Parenthood as Self-extension. Apart from the parental relationship and its valuable elements, engaging in parenting a child is a way of extending oneself into the future, being part of a project that outlasts one's own life and thus being part of the world after one's death. The ability to engage in a form of self-extension is - as argued above - important: parenting, if done well, amounts to making an important contribution to a life that will (hopefully) outlast one's own. It is a way to engage in creative self-extension, 'giving a child what she needs to develop from a vulnerable new-born into an autonomous adult is about as creative as it gets' ${ }^{54}$ Moreover, it is a very democratic way to extend oneself into the future: not everybody is able to contribute to big projects that span generations. Not all of us can be Verdis, Kants or Curies, but all those who are good enough parents can realize self-extension in this way. Parenthood is a democratic way of self-extension.

However, liberals will want to limit the extent to which parents can mold their children in their own image: parents should not treat their children as extensions of themselves. Children are separate persons who need to develop and pursue their own plans. ${ }^{55}$ Parents may engage in self-extension 'out of commitment to the child and the relationship', but not 'out of commitment to that value or project ${ }^{\text {. }} .{ }^{56} \mathrm{I}$ do not

\footnotetext{
52 Rawls, A Theory of Justice, p. 427.

53 Richard Arneson, "What do We Owe to Poor Families?" Law Ethics and Philosophy, Vol. 2 (2015), p. 9 .

54 Brighouse and Swift, Family Values, p. 102.

55 See Brighouse and Swift, ibid, p. 102; Clayton, op. cit.

56 Brighouse and Swift, ibid., p. 102; but see McLeod, C. "Parental Competency and the Right to Parent" in Sarah Hannan, Samantha Brennan and Richard Vernon, eds., Permissible Progeny (Oxford: Oxford University Press, 2015), pp. 227-245.
} 
think this limitation undermines the possibility of self-extension, as it excludes only particular ways of self-extension (those that involve purposely shaping the child's values). ${ }^{57}$

Parenthood or procreation? Suppose the argument for the right to parent presented so far is correct. This does not yet give us a right to procreate. One does not need to procreate in order to parent, and nothing in the account given suggests there is a right to create the child one wants to parent. If children where indeed created in baby-factories, we would have reasons for distributing them widely to willing and able parents. What this argument establishes is that people have an important interest in there being enough children to parent. The following claim can be defended:

Aggregative parenthood argument: people have a weighty interest that some people have on aggregate sufficient children to provide all sufficiently good prospective parents with children - not necessarily their own biological child.

Children, obviously, do not come from baby-factories. How should reproductive labor be distributed among those who are willing and able to produce offspring? There are three principle reasons why a right to procreate should be widely distributed among willing and capable parents. First, there are good reasons for thinking it impermissible to take children away from gestational procreators to distribute to willing and able parents. ${ }^{58}$ Distributing procreative entitlements widely limits the need for re-allocation.

Second, transferring children from their procreators to parents is often not an option. Even though adoption gives access to the goods of parenthood, as things stand there are only a limited number of children available for adoption, not necessarily because there are no children in need of parents but because it is difficult for aspiring adoptive parents to access children in need of parents. There are important legal and financial restrictions (age, income), limits to international adoption, and adoption is often prohibitively costly. ${ }^{59}$ In the world as it is, procreation is the only way to access parenthood for many. ${ }^{60}$ There are good moral reasons to remove some of the unnecessary barriers to adoption, whether legal, social or financial. This is so not only for the sake of prospective parents, but especially for the sake of children in need of parents. If adoption became much easier, the parental argument for a right to

\footnotetext{
57 See Harry Brighouse and Adam Swift, "The Goods of Parenting," in Françoise Baylis, F. and Carolyn MacLeod, eds. Family-Making (Oxford: Oxford University Press 2014), p. 24.

58 See Anca Gheaus, "Is the Family Uniquely Valuable?" Ethics and Social Welfare, Vol. 6, No. 2 (2012): 120-131.

59 Arguably many of these restrictions need to be loosened, and adoption should perhaps be encouraged as an alternative to procreation. See De Jurgen Wispelaere and Daniel Weinstock, "Privileging Adoption over Sexual Reproduction," in Sarah Hannan, Samantha Brennan and Richard Vernon, eds., Permissible Progeny (Oxford: Oxford University Press, 2015), pp. 208-226.

60 There might be many children in need of adoption, but prospective adoptive parents often do not have the possibility to adopt children in need of adoption due to legal and financial constraints. In a more egalitarian world, there might be less children available for adoption, because there would be less unwanted pregnancies, fuller control over procreative freedom, and no people unable to care for their biological children.
} 
procreate would be weakened, because good alternative routes to acquire the goods of parenthood would be available.

Third and finally, people want to have biological offspring. Although preference satisfaction is, in itself, not the aim of the theories of justice under discussion here, a distribution that satisfies, all other things being equal, people's weighty (non-objectionable) preferences is better than one that does not. We can, then, offer a conditional extension of the right to parent to a right to procreate for prospective parents:

Individual parenthood argument: people have a weighty interest in procreation if it is a necessary step to access the goods of parenthood.

An important limit to the argument so far should be noted. The right to procreate is conditional on some suitable rearer having the intention to parent the child. If one does not create the child whose existence one initiates with an eye on providing someone - the procreator or someone else - access to parenthood, the argument so far offers no support for the right to procreate. This argument does not provide support for a right grounded in the desire to experiencing gestation, or the disire to create genetic offspring: the right is conditional on there being parents willing and able to enjoy the goods of parenthood.

A right to more than one? Do the arguments discussed so far count for the first as well as for the second, third (etc.) child? It seems not. If one has a right to be a parent, this right is fulfilled once one has one child (provided, of course, it grows up healthy). The second child does not provide access to the goods of parenthood, since one has parental relationships with the first child - unless the additional child is created so that others who cannot procreate will be able to parent a child. This is not simply a matter of the diminishing marginal utility of the accessed goods, it is a qualitative difference: having one child to parent relieves one of not having parentchild relationships (in the parental role), having an additional child does not. ${ }^{61}$

This is not to say, of course, that there is nothing valuable at stake in having a second child, or that having more loving, intimate relationships is not better than having just one. Neither is it to say that people never have the right to have more than one child. However, given the lesser moral importance of being able to parent a second child, this right will be more easily overridden by other considerations. The right to the first child merits much greater protection against competing considerations because of the different goods at stake.

\section{Parenting Biological Offspring}

In earlier sections I claimed that genetic extension in itself cannot ground a right to procreate, but that a right to parent can ground a limited and conditional right to procreate. Can we argue that some value in procreation may be explained by the value of having biological offspring?

\footnotetext{
61 There may be other relevant reasons for a right to have additional children. Perhaps children have a fundamental interest in having siblings. This might entail that parents have a right to an additional child. More needs to be said about this.
} 
There are two ways of having biological offspring. A child that shares (part of) one's genes is genetic offspring. A child that one gestated is one's gestational offspring. In most cases, the two go together, but this is not necessarily so (think of gestational surrogacy). Although they may be intensively involved in their partners' gestational process, men can only have biological offspring of the first, genetic, kind. Velleman points to the importance of genetic ties, but he aims to show that children have an interest in being parented by their genetic parents. ${ }^{62} \mathrm{He}$ does not show that prospective procreators have an interest in genetic offspring. Gheaus points to the relevance of gestation for claiming the right to parent a particular child (the one that the prospective parents gestated). ${ }^{63}$ She does not establish the value of gestating in the first place. In order to establish that having biological children is valuable, one would have to show the value in having genetic and/or gestational offspring. ${ }^{64}$

Can a more direct case for procreation be made, by appeal to the value of having biological offspring? Some philosophers claim that having biological offspring is protected by a right, but little argument is offered. ${ }^{65}$ They do not show "why that interest, however elaborated, should be regarded as important'. ${ }^{66}$ Brighouse and Swift's own account of the value of parental relationships does not depend on people raising biological children of the gestational and/or genetic kind. They argue that those arguing there is something special about genetic parenthood: "neglect the profound respects in which raising a child just is the same experience whether the child is a genetic descendant or not - the day-to-day and minute-to-minute burdens and joys of caring for and overseeing her development are most of what child rearing consists in and most of what gives it value'. ${ }^{67}$

Plausible defenses of the importance of parenting biological offspring are scarce, but they may be constructed on arguments present in the existing literature on related topics. Without going into details, let me suggest a few. One could appeal to the largely involuntary but strongly engrained nature of people's attachment to parenting biological children. Drawing on Dworkin one could argue that if a preference for biological offspring is not voluntarily acquired, there is a way in which those who have this preference suffer from a handicap of sorts. ${ }^{68}$ However, Dworkin believes people should only be compensated if they do not endorse their preference. People do not usually regret having this preference, and may even find the characterization of it as a handicap offensive. On a Dworkinian approach, the case for preferential treatment of the preference for biological offspring seems hard to make. ${ }^{69}$

\footnotetext{
62 See David Velleman, "Family History," Philosophical Papers, Vol. 34, No. 3 (2005): 357-378.

63 See Gheaus, "Right to Parent?"

64 See for example Brake, op. cit.

65 See Mary Warnock, Making Babies: Is there a Right to Have Children? (Oxford; Oxford University Press, 2001); Robertson, op. cit.; Edward Page, "Parental Rights," Journal of Applied Philosophy, Vol. 1, No. 2 (1984): 187-203.

66 Brighouse and Swift, Family Values, p. 105.

67 Brighouse and Swift, Family Values, p. 107.

68 See Dworkin, R., Sovereign Virtue (Cambridge, MA: Harvard University Press, 2000.), p. 297.

69 Paul Bou-Habib's hypothetical insurance argument for parental subsidies may be tweaked to include biological parenthood. If enough people would insure for ending up with the strong desire to have biological children to parent (this insurance may, for ecological reasons, be more expensive than the insur-
} 
Welfarists could point out that their view, in contrast to the views under consideration here, can accommodate the intuition that biological parenthood matters. Taking a Cohenian line on expensive tastes, one could argue that although parents do not regret their preference for biological offspring, they $d o$ regret its expense. ${ }^{70}$ Letting people decide between freeing up resources or abandoning expensive preferences, as a Rawlsian or Dworkinian may suggest, would be unacceptable on a Cohenian view if the preference is one that people greatly identify with. ${ }^{71}$ The case for the value in biological parenthood, if no better argument can be offered, is weak at best for non-outcome focused theorists. Perhaps other arguments can be offered: I, for one, find it difficult to rid myself of the intuition that something valuable is at stake.

\section{An Indirect Justification for a Limited and Conditional Right}

In this paper I provide an indirect defense for a limited and conditional right to procreate within a broadly liberal framework. By an appeal to the different goods at stake in the practice of procreation and parenthood, both on the individual and the collective levels, I have tried to show that there are several goods at stake in procreation that support a pro-tanto case for a right to procreate. Procreation is valuable - in some ways constitutively, in some ways instrumentally - because it is crucial for the creation and distribution of several important goods. The argument is conditional, because procreation is protected by a right only in so far as the procreative act gives access to these goods. A right to procreate, say, out of curiosity is not supported by the arguments provided. The right is limited, procreation being protected up to the point necessary to give people access to these goods: it is not a case for a right to have as many children as one wants.

Does this mean we should think about the creation of a child as a mere means to other ends? Although procreation is not merely instrumental, I do argue it is valuable largely because something else is valuable. Two concerns arise. First, why can't we just say that procreation is important in its own right? Second, does this account treat future children as mere means to an end?

The first concern is about what kinds of considerations are admissible within the constraints of liberal justification. That procreation is valuable in itself, not because of the goods it provides access to, or at least that procreation is considered

\footnotetext{
Footnote 69 (continued)

ance for parenthood simpliciter), procreative subsidies would be justified. However, if most of the goods result from parenthood and not procreation, perhaps premium buyers would not buy insurance for procreative parenthood. Paul Bou-Habib, "Parental Subsidies: The Argument from Insurance," Philosophy, Politics and Economics, Vol. 12, No. 2 (2012): 197-216.

70 Cohen argues that 'all appropriately involuntary brute expensive tastes warrant compensation.' Endorsement does not undermine this: 'precisely because they did and do identify with it, and therefore cannot reasonably be expected to have not developed it or to rid themselves of it'. G.A. Cohen, On the Currency of Egalitarian Justice (Princeton: Princeton University Press, 2011): pp. 88-89.

71 'taking responsibility for our tastes and preferences, whether or not they have arisen from our actual choices, is a special case of that responsibility. As citizens with realized moral powers, this is something we must learn to deal with'. Rawls, Political Liberalism, p. 185.
} 
valuable in its own right may be correct. Unless one shows that procreation has noninstrumental value that qualifies as a distribuenda of justice, liberal theorists cannot ground a right in these claims about the good. People may believe procreation to have be valuable, people may act on this belief, yet these are not reasons to treat people's capability to engage in this particular activity with special attention from the point of view of justice.

The second concern is, up to a point, correct: it does treat children as means, and the extent to which procreation is labelled valuable depends on children's capacity to deliver these goods as children, caregivers, economic agents, or future valuers. However, it does not do so impermissibly. One cannot treat a child as an end in itself before it exists. What matters is that the child is not used as a mere means (although of course people may still instrumentally benefit from the child) but as an end in itself once it exists.

This is not an exhaustive account of the value of procreation. It only offers an account of the role the value in procreation can play within liberal justification, assuming reasonably fair distribution of goods. The paper did not comprehensively discuss all possible arguments of this kind. Moreover, in non-ideal circumstances, there may be other things that make procreation valuable or permissible. ${ }^{72}$ How we should think about the permissibility of procreation in the face of poverty, gender inequality, lack of contraceptives, and the like is another question in which the considerations offered above will have to figure. They will have to be supplemented by many other considerations.

Acknowledgements Special thanks to Axel Gosseries, who has commented on several earlier drafts of this paper, and to Anca Gheaus for elaborate and constructive comments. For helpful comments and discussion I want to thank Andreas Albertsen, David Axelsen, Juliana Bidadanure, Sandrine Blanc, Amneris Chaparro, David de la Croix, Marc Davidson, Marcus Düwell, Nir Eyal, Cristian Fatauros, Thomas Ferretti, Soren Flinch-Midtgaard, Iñigo González Ricoy Siba Harb, Colin Hickey, Liam Shields, Maxime Lambrecht, Kasper Lippert-Rasmussen, Lukas Meyer, Thierry Ngosso, Lasse Nielsen, Joachim Nieuwland, Tom Parr, Georgios Pavlakos, Ingrid Robeyns, Serena Olsaretti, Pierre Etienne Vandamme, Philippe Van Parijs and Daniele Zwarthoed.

I want to thank audiences at the University of Louvain, Leiden University, Glasgow University, University of Aarhus, Oxford University, Utrecht University and at the UCAC in Yaoundé.

Open Access This article is licensed under a Creative Commons Attribution 4.0 International License, which permits use, sharing, adaptation, distribution and reproduction in any medium or format, as long as you give appropriate credit to the original author(s) and the source, provide a link to the Creative Commons licence, and indicate if changes were made. The images or other third party material in this article are included in the article's Creative Commons licence, unless indicated otherwise in a credit line to the material. If material is not included in the article's Creative Commons licence and your intended use is not permitted by statutory regulation or exceeds the permitted use, you will need to obtain permission directly from the copyright holder. To view a copy of this licence, visit http://creativecommons.org/licen ses/by/4.0/.

Publisher's Note Springer Nature remains neutral with regard to jurisdictional claims in published maps and institutional affiliations.

72 See Meijers, "Climate Change", op. cit. 